\title{
INDONESIA CIGARETTE FACT IN TAUFIQ ISMAIL POETRY
}

\author{
Dzikrina Dian Cahyani' ${ }^{1}$, Retma Sari ${ }^{2}$ \\ \{dzikrina@untidar.ac.id $\left.{ }^{1}\right\}$
}

\begin{abstract}
${ }^{1,2}$ Tidar University, Kapten Suparman 39 st, Magelang, Central Java, Indonesia
Abstract. The differences of opinion about the smoking problems in Indonesia still continue to be discussed in various ways, including Indonesian literary writers such as Taufiq Ismail. Some of his poems discussing the problem of smoking are Tuhan Sembilan Senti, Indonesia Keranjang Sampah Nikotin, dan Perokok adalah Serdadu Berani Mati. This research was conducted to find criticisms related to smoking problems in Indonesia described in three of Taufiq Ismail's poems. The theoretical approach used in this study is the sociology of literature theory to discuss smoking criticisms contained in those poems. Descriptive Qualitative was used here. The method of collecting data noted carefully. The results of the study showed that the poetry of Taufiq Ismail's work revealed some criticisms of the smoking problems in Indonesia. These criticisms included the indecisiveness of smoking regulation in Indonesia, the bad behavior of Indonesia smokers, and the responsiveness of passive smokers in Indonesia
\end{abstract}

Keywords: Cigarette fact, the danger of cigarette, poetry

\section{INTRODUCTION}

The phenomenon of smoking habits is where it is very easy to find people to smoke. Circulation of cigarettes also has a trend that continues greatly from time to time. The survey of Global Adult Tobacco in 2018 shows that the number of smokers in Indonesia currently stands at $67 \%$ of the total population of around 178 million inhabitants. The results also show that Indonesia is a country that has several smokers, especially the highest number of smoking men in the world.

Smoking consumption in Indonesia is raising seriously and some dilemmas appear in finding the solutions. On one side, cigarettes have good value in the economic field, but on the other hand, health and social impacts can also be very detrimental. Pros and cons in society are also always appearing against in every government-designed policy. It is also believed that cigarette users in Indonesia are almost half of Indonesians. However, it is always defined by smoking groups (smokers), those who are against no-smokers, and on the contrary.

Some views about the smoking group so that it is still interesting to attract the attention of various people, including Indonesian writer, Taufiq Ismail. Some of his brilliant works about smoking Tuhan Sembilan Senti, Indonesia, Keranjang Sampah Nikotin, dan Perokok adalah Serdadu Berani Mati. From those, Taufiq Ismail gives detail information and critic smoking phenomenon in Indonesia. Those poets describe the social reality about the behavior of 
smokers and their environment, various diseases caused by smoking and other problems appear because of smoking.

Some criticisms were revealed with simple predictions that were on target. Another interesting thing is the smoking phenomenon in each and each of them flowing and not transparently expose about the differences in opinions on smoking. Taufik Ismail exploits irregularities and satire about irregular problems in Indonesia. Readers are encouraged and given space to think, ponder, and consider good or bad smoking.

Using a unique idea in his poetry, Taufik Ismail sounds about some criticisms in Indonesia. Some criticisms were revealed with simple predictions that were on target. Another interesting thing is the smoking phenomenon in every one of them flowing and not transparently talking about the differences in opinions on smoking. Taufik Ismail exploits irregularities and satire about irregular problems in Indonesia. Readers are encouraged and given space to think, ponder, and consider the good or bad impact of smoking.

This research aims to discuss cigarette facts in Indonesia contained in the three works of Taufiq Ismail. Some previous studies discussed the problem of smoking in Indonesia, such as Hamdan in 2015 [1]. This research was conducted in an experimental research design using a Factorial design. The results showed that a warning picture of diseases caused by smoking, accompanied by a short warning writing could be effective in influencing people's desire to smoke. Masitha Nur Amalia in 2017 wrote Analysis of the Effects of Cigarette Consumption on Labor Productivity in Indonesia.[2] The results of the study explain the significant influence of smoking on labor productivity in Indonesia. The data used are secondary data obtained from Indonesian Family Life Survey 5 (IFLS 5) with 7099 selected respondents. The analysis technique uses multiple linear regression analysis

Based on the previous study, this research has some differences. This research focuses on the problems that appear in those Taufik Ismail's poetry. The theoretical approach used is sociological literature which explains that literary are social products and able to explain social phenomena. Faruk [3] also argues that the use of language in literature once weakened responses to literary works as just expressions of individual or subjective experiences of authors. The individual experience and subjective authors change into the collective effects that lead to a literary work by language media. The use of language in literary works will automatically change the understanding of the subjective perspective of the creator into collective and social understanding. Literature theorists view literary works that can be approached with mimetic orientation. Literature is the imitation of social reality in society. Pradopo [4] explains based on Abram's opinion about the fundamental principles of the literary sociology of literary works (centrality) as a reflection of the community at the time the literary works were written.

There are three orientations of literary work according to Ian Watt expressed by Faruk [3]. However, in this research, the focus is just on two orientations which analyze that orientations reflect the public's reflection (mimetic) and social literary functions. The important thing in mimetic approach are (a) how far literature can reflect the community when the literature made; (b) how far the author's background influences his portrayal of the people he wants to convey through his work; (c) how far the literary genre (poetry) can be used by the author to represent people in society. While the function of social literature are (a) how far literature can function as a spearhead of its society; (b) how far literature is only as a comforter; and (c) how far literature becomes a factor in the possibility of transforming society and becoming entertaining.

Based on the understanding, in this study, the orientation of mimetic in the literary work focused on revealing how Taufiq Ismail's poetry was able to choose things related to the 
problem of smoking in Indonesia. The approach of the literary social function is a concern is that literary work can function as a remodeling of the community through critical ideas about smoking problems in Indonesia in poetry by Taufiq Ismail.

\section{METHOD}

This research uses a qualitative type in which the results of descriptive analysis. [5] The data used are the stanzas in the Taufiq Ismail banners, namely Tuhan Sembilan Senti, Indonesia Keranjang Sampah Nikotin, dan Perokok adalah Serdadu Berani Mati. The data collection technique used was listening and note-taking. The obtained data from the listening of three poetry of Taufiq Ismail focused on smoking problems then recorded, then it is revealed in their meanings. These steps are used to understand the input because the use of words in the poem or poetry is different from the meaning of conventional words. The language of poetry has particularities, uniqueness, and in general, has connotative meanings. After that, the results continue to analyze to find criticism of smoking problems in Indonesia which was written in Taufiq Ismail's poetry. [6]

\section{RESULT AND DISCUSSION}

Taufiq Ismail's poetry which described the problem of smoking in Indonesia were the Tuhan Sembilan Senti, Indonesia Keranjang Sampah Nikotin, dan Perokok adalah Serdadu Berani Mati. Tuhan Sembilan Senti (TSS). All poetry has their own specifications when they describe smoking. Tuhan Sembilan Senti (TSS) tends to describe the reality of smokers based on their profession and the scope of activity. Keranjang Sampah Nikotin (IKSN) described the phenomenon of industrial development and the regulation of cigarettes in Indonesia. Perokok adalah Serdadu Berani Mati (PSBM) described the various damages and various diseases caused by smoking.

The description of cigarette problems in three Taufiq Ismail poetry is quite complete to present and expose social facts about smoking in Indonesia. Some issues talk about the indecisiveness of smoking regulation in Indonesia, the attitude of Indonesian people towards smokers, and various substances contained in cigarettes as well as their bad effects.

\subsection{Indecision of Cigarette Regulation in Indonesia}

The application of smoking regulation in Indonesia is still very baggy and there are many tolerances in its enforcement. Regulation is defined as rules in the social circumstance that manage behavior in the community that must be obeyed. In the poetry Keranjang Sampah Nikotin (IKSN), it illustrated that Indonesia provides an ample space for the body of developing manufacturers, marketing, and consumers of cigarettes. From the poetry title, Indonesia was called a "dustbin," which was literally a place of worship for the removal of useless goods. The word "nicotine" in question is none other than cigarette smoking in a doctor containing one of the ingredients of nicotine. From the title of the poem, the statement illustrated that Indonesia is as if the place of disposal of goods that are considered dirty

The regulation of smoking in Indonesia has continued to be reviewed and changed from time to time. However, in fact, the level of consumption of cigarettes in Indonesia was rising rapidly. This case showed that the regulation did not become accurate for binding. Indonesia is westernized in IKSN poetry, such as a door to a very wide open door for many cigarettes. The meaning of "home" is the building for the place where the millions of people become citizens 
of the country. The meaning of "door" and "gate" in poetry is the place that comes out and enters. This "gate" is a regulation that regulates the exclusion of smoking in Indonesia. In this poetry, it is described that the opening gate is open which illustrates the regulation of the incomplete climate of the inclusion and development of smoking in Indonesia. This is proven by data from the Indonesian Ministry of Industry [7] which shows that there are 423 industrial companies that are scattered throughout the territory of Indonesia. These companies consist of small and large industries which, of course, most of their understanding is foreign. A large number of cigarette manufacturers showed that the regulation of smoking cigarettes was weak in regulating the development rate of the smoking industry in Indonesia

\begin{abstract}
//Semua itu, karena gerbang di halaman rumah kita terbuka luas, kita tergoda oleh materialisme dan disuap kapitalisme fikiran sehat kita kaki dan tangan kanan kiri terbelenggu dengan ramah dan sopan kiriman sampah itu diterima.(IKSN)
\end{abstract}
//Di pintu depan bandara, Karen aurgennya modal mancanegara, karena tak tahan nikmatnya komisi dan upeti, //(IKSN)

Several factors can influence the growth of the cigarette industry in Indonesia. One of them is expressed in IKSN poetry, that is

\title{
karena //tergoda oleh materialism dan disuap kapitalisme//karena ungennya modal dan tak tahan nikmatnya komisi dan upeti//.
}

The reasons for the weak regulation of cigarettes described in this poem because in fact, cigarettes are becoming a best-selling commodity in the middle of Indonesian society. Economically, cigarette companies make billions of profit annually and cigarette excise is the mainstay of the state's cash income. Proportion and Estimation of Cigarette Tax Revenue for Each Province Fiscal Year 2018 [8] is targeted to receive a tobacco excise tax of Rp148,230,000,000,000.00. It is estimated that $2 \%$ of the tobacco revenue excise target is excise tax on iris tobacco which is not included in the Cigarette Tax object, so the excise tax used as a basis for calculating the 2018 TA Tax of Rp145,265,400,000,000.00 (98\% of the revenue target) tobacco product excise tax) and estimated cigarette tax receipts as stipulated in the Decision of the Director General of Fiscal Balance in the amount of Rp14,526,540,000,000.00

Based on quotations from the poem IKSN, illustrating that the flourishing of cigarette manufacturers in Indonesia is due to the weak regulation of cigarettes in Indonesia. Policymakers are so helpless as if a healthy mind, feet and hands are shackled and unable to do anything about the current development of cigarettes in Indonesia. In addition, every cigarette regulation in Indonesia in the poem says "very friendly and polite". Interpreted in KBBI, the word "friendly" is interpreted kindly and the word "polite" can be interpreted as respectful or reverent. From the choice of diction, cigarette regulation is described as giving a great opportunity and giving free space to the cigarette industry in Indonesia. Regulations made like it cannot filter and limit the entry of cigarette companies, especially foreign cigarette companies in Indonesia. The developing of foreign cigarette companies in Indonesia actually get lots of restrictions in their own country. Conversely, in Indonesia which is in 
stated IKSN as "the third country" actually the foreign cigarette industry is given much discretion to develop and progress.

//Keranjang sampah ini luar biasa kapasitasnya.

Pedagang-pedagang nikotin yang dinegeri asalnya babak belur digebuki.

Di pengadilan bermilyar dolar dendanya.

//Ketahuan penipunya dan telah memenuhi jutaan penghisapnya.// (IKSN)

//Diusir terbirit-birit akhirnya berlarian ke dunia ketiga.

Dan dengan rasa rendah diri luar biasa kita sambut mereka bersama-sama.// (IKSN)

//Demikian dengan rasa hormat yang lumayan berlebihan.

Para pedagang nikotin dari negeri jauh di tepi langit sana.

Penyebar penyakit rokok dan pencabut nyawa anak bangsanya.

Terlibat pengadilan dan tertimbun bukti.

Di negeri sendiri telah diusiri dan dimaki-maki.

Ke dunia ketiga mereka melarikan diri// (IKSN)

//Pabrik-pabrik mereka ditutup di negeri sendiri.

Lalu didirikan di Dunia Ketiga, termasuk negeri kita ini.//

Di depan hidung kita penyakit dipindah kesini.

Dan untuk mereka kita hamparkan merahnya permadani.

Lalu bangsa kita ditipu dengan gemerlapannya advertensi.

Inilah nasib bangsa yang miskin dan pemerintah yang lemah.

Semua bertumpu pada pemasukan uang sebagai orientasi. (IKSN)

Indonesia is now a place or container to accommodate all types of cigarette production that have been considered as garbage or useless goods in the country of origin. The history of cigarettes originally began around 1556 with the development of tobacco plants in the European region. Then around the year 1571, the sugar cane plant was widespread in the European region. Some countries that became the beginning to develop tobacco are France, Portugal, Spain and the United Kingdom. Furthermore, around 1600 a law was made which restricted the plantation and sale of tobacco leaves. That is why some of these countries carry and develop tobacco plantations in the colonies in the Americas, Asia and Africa. The spreading of tobacco trade reaches up to the Middle East also. In Indonesia the development of the cigarette industry was carried out by the VOC by expanding land to serve tobacco. Around 1840 Governor Van den Boch imposed a forced tobacco cultivation system [9].

\subsection{The Substances of and danger of consuming}

It is known that smoking has two opposing sides. Economically, cigarettes can contribute to very high APBN funds. However, in terms of health, cigarettes have a negative impact on its users and people who are near smokers. Cigarettes become goods that provide comfort and 
enthusiasm. The substance of cigarettes is a danger that causes bad things if consumed. Cigarettes contain various substances that harm the human body. Based on government regulation 2012 [10], states that cigarettes, as a result of tobacco products contain addictive substances. Addictive substances are substances that cause addiction or dependence that endanger health by marked, such as changes in behavior, cognitive, and physiological phenomena in having a strong desire to consume it. The problems in controlling to use it, giving priority to tend to smoke than other activities, increasing tolerance and causing state of substance withdrawal symptoms. The nicotine is a substance or pyrrolidine compound found in Nicotiana tabacum, nicotiana rustica and hother species or its addictive synthetic can cause dependence.

Some of the danger ingredients of cigarettes in Taufiq Ismail's poetry. The parts of poetry which are discussed about the danger of cigarette described clearly in Tuhan Sembilan Senti (TSS) and Perokok adalah Serdadu Berani Mati (PASBM). In TSS poetry, some critical ideas about the dangerous effects of smoking are also explained. This critical notion is illustrated in TTS poetry by comparing diseases caused by smoking with diseases caused by khamr. It is said //25 penyakit ada dalam khamr // 15 penyakit ada dalam daging khinzir (babi). Daging khinzir diharamkan. // 4000 zat kimia beracun ada pada sebatang rokok. The comparison is like to give readers an understanding that these cigarettes are not legally religious items, especially in Islamic law that is considered trivial. The cigarettes is comparable to eat pork and kamr which is clearly forbidden.

//Rokok, abang kandung narkoba ini tak tertandingi dalam soal adiksi. 4000 macam racun didapatkan sepanjang sembilan senti.// (PASBM)

//25 penyakit ada dalam khamr. Khamr diharamkan. 15 penyakit ada dalam daging khinzir (babi). Daging khinzir diharamkan. 4000 zat kimia beracun ada pada sebatang rokok. sejak tadi pagi sudah 120 orang di Indonesia mati karena penyakit rokok. Nikotin lebih jahat penularannya ketimbang HIV-AIDS.

Asap rokok di ruangan ber-AC itu makin pengap, dan ada yang mulai terbatukbatuk. Pada saat sajak ini dibacakan malam hari ini, sejak tadi pagi sudah 120 orang di Indonesia mati karena penyakit rokok. //(TSS)

More detailed explanation of various diseases caused by smoking is illustrated in the poetry of Perokok adalah Serdadu Berani Mati. It was explained that by only enjoying cigarettes for a short time, smokers would be faced with 25 types of diseases. Some of these diseases are mentioned in detail by Taufiq Ismail through the poem PASBM. Cigarettes can damage several important human organs, namely brain, lungs and heart.

//Untuk kenikmatan 5 menit mereka tidak peduli 25 macam penyakit yang dengan gembira menanti-menanti.

Saat untuk menerkam dari setiap penjuru dan sisi.

Paru-paru obstruksi kronik bronkhitis kronik dan emfisema. 
Gangguan jantung pembulu darah arteriosklerosis hipertensi dan gangguan pembulu darah otak. kanker rongga mulut, nasopharynx, oropharynx, hypopharynx dan rongga hidung.

Lalu sinus paranasal, larynx, esophagus dan lambung.

Radang pankreas, hati, ginjal, ureter dan kandung kemih.

Radang cervix uteri dan sumsum tulang, infertilitas dan impotensi.

Daftar ini belum disusun secara alfabetis, dan sebenarnya (ini rahasia profesi medis) penyakit yang 25 ini cuma nama samaran julukan pura-pura saja.

Nama aslinya penyakit rokok.//(PASBM)

The above poetry's verse is very specifically mentioned about various diseases caused by smoking. Smoking can interfere with the work of heart, arteries,s hypertension arteriosclerosis and brain blood, vessel disorders. oral cancer, nasopharynx, oropharynx, hypopharynx and nasal cavity. // Then the paranasal sinuses, larynx, esophagus and stomach. Inflammation of the pancreas, liver, kidneys, ureters and bladder. Inflammation of the cervix and bone marrow, infertility and impotence.

\subsection{Bad habits of Indonesian smokers}

Smokers in Indonesia often ignore and appeals governments' warning and intellectuals regarding the dangers of smoking. He considered that the socialization held by the government and intellectuals is not important. Smoking has become an ingrained culture for Indonesians. In fact, there are some intellectuals who are predicted as a role model of society. In Taufik Ismail's poem, Tuhan Sembilan Senti , was written that a teacher who incidentally must be digugu (obeyed) and imitated is smoking also. Nowadays, it is assumed that it is not surprising that students smoke because their teachers' habit. That fact was stated by Taufik Ismail in his poem entitled Tuhan Sembilan Senti.

//Di sawah petani merokok,/di pabrik pekerja merokok,/di kantor pegawai merokok,/di kabinet/menteri merokok,/di reses parlemen anggota DPR merokok,/di Mahkamah Agung yang bergaun toga merokok,/hansip-bintara-perwira nongkrong merokok,/di perkebunan pemetik buah kopi merokok,/di perahu nelayan penjaring ikan merokok,/di pabrik petasan pemilik modalnya merokok,/di pekuburan sebelum masuk kubur orang merokok./Indonesia adalah semacam/firdaus-jannatu-na'im sangat ramah bagi perokok,/tapitempat siksa kubur hidup-hidup bagi orang yang tak merokok./Di balik pagar SMU murid-murid mencuri-curi merokok,/di ruang kepala sekolah...ada guru merokok,/di kampus mahasiswa merokok,/di ruang kuliah dosen merokok,/di rapat POMG orang tua murid merokok,/di perpustakaan kecamatan ada siswa bertanya lapakah ada buku tuntunan cara merokok./Di angkot Kijang penumpang merokok,/di bis kota sumpek yang berdiri yang duduk orang bertanding merokok,/di loket penjualan karcis orang merokok,/di kereta api penuh sesak orang festival merokok,/di kapal penyeberangan antar pulau penumpang merokok,/di andong Yogya kusirnya merokok,/sampai kabarnya kuda andong minta diajari pula merokok.// 
In Indonesia, there are government regulations concerning the safeguarding of substances containing additives in the form of tobacco products for health, but in fact, cigarettes still roam freely in this country. The weakness of regulation makes smokers relaxed and innocently smoke everywhere. Appeals and prohibitions that are written implicitly have been distributed; even there is a pack of cigarettes itself. The appeal is written, "Smoking can kill you." The sentence was identified by Taufik Ismail in his poetry entitled Perokok AdalahSerdadu Berani Mati. How come? Smokers have read the sentence, but they do not care. In fact, smoking does not only kill smokers but also surrounding them. It will affect profoundly because passive smokers have a more dangerous impact than active ones

According to the World Health Organization or WHO abbreviated if based on the percentage of the population, Indonesia is listed as the largest smoker in the world. $76 \%$ of men aged 15 years registered as smokers. From this data it is not surprising that Taufik Ismail gave the title of his poem with Indonesia Keranjang Sampah Nikotin. Not only that, in the poem of Tuhan Sembilan Senti, he also revealed that people who smoke are the same as digging their own graves.

\section{//di pekuburan sebelum masuk kubur orang merokok//}

How ignorant smokers with the dangers caused by smoking. Unfortunately, the people of Indonesia are still relatively low in terms of reading culture. Indonesia is ranked second in the world from the bottom in terms of interest in reading. Of the 62 countries, Indonesia is ranked 60th. In fact, infrastructure in supporting Indonesia's reading interest exceeds European countries. That is due to the lack of Indonesian people in utilizing the facilities provided by the government so that socialization needs to be held in calling for the dangers of smoking. Not only the students and students, but it needs to be socialized in the villages so that the whole community knows about it.

\subsection{Passive Response of Passive Smokers in Indonesia}

The problem of smoking in Indonesia is not merely the fault of active smokers, but also the mistakes of passive smokers. Passive smokers are people who inhale cigarette smoke that is inhaled by active smokers. This is more dangerous because not only nicotine and other harmful substances are inhaled, but also carbon dioxide exhaled by active smokers. The mistake of passive smokers is not daring to admonish active smokers expressly. The culture of tolerance in Indonesia can also be fatal if it used in the wrong time, place and situation. Excessive tolerance makes people dare not express their arguments, including in the case of smoking. In Javanese, the culture is known as "rikuh"or awkward culture. Culture "rikuh" is a culture when someone wants to reprimand the mistakes of friends or partners to talk but afraid of offending the partner to talk so that the rebuke can not be conveyed or, in other words, buried alone. Indonesian culture, especially Javanese culture, is also famous for being a closed or not transparent culture. They tend to use pragmatic sentences to reprimand someone; for example, there is someone who smokes even though in front of him, a mother is holding a baby, then the baby's mother says, "Mas, please help us. It is a baby here," if the smoker does not understand the mother's intentions, then a pragmatic failure occurs. Such is the culture of Indonesia that makes Indonesian people who do not smoke forced to become passive smokers. This was written by Taufik Ismail in his poetry entitled Indonesia Keranjang Sampah Nikotin, such follows 


\begin{abstract}
I/Di pintu depan bandara, karena urgennya modal mancanegara, karena tak tahan nikmatnya komisi dan upeti, dengan membungkuk-bungkuk kita berkata begini,/"Silahkan masuk semua, silakan./Monggo, monggo mlebet, dipun, sakecakaken./Sog asup sadayana, asup, asup. /Ha lai ka talok, bahe banalah angku, bahe banalah."/Keranjang sampah ini luar biasa kapasitasnya. /Pedagang-pedagang nikotin yang dinegeri asalnya babak belur digebuki./Di pengadilan bermilyar dolar dendanya./Ketahuan penipunya dan telah memenuhi jutaan penghisapnya. IDiusir terbirit-birit akhirnya berlarian ke dunia ketiga./Dan dengan rasa rendah diri luar biasa kita sambut mereka bersama-sama./" Monggo, monggo den, linggih rumiyin./Ngersakaken menopo den bagus./Mpun, ngendiko mawon. Aih aih si aden, kasep pisan. Tos lami, sumping, di dieu, Indonesia? Alaa, ranca bana oto angku ko. SSabana rancak. /Bao caronyo kami, supayo ... "/Demikian dengan rasa hormat yang lumayan berlebihan./Para pedagang nikotin dari negeri jauh di tepi langit sana./Penyebar penyakit rokok dan pencabut nyawa anak bangsanyall
\end{abstract}

The weakness of government regulations also makes passive smokers cornered. If, in Indonesia has strict regulations, for example, people who smoke are subject to a large number of fines, active smokers are afraid and passive smokers can reprimand firmly because there are regulations that are used as reinforcement of prohibitions and threats. That already applies in our neighboring country, Singapore. Singapore is well-known as a fines country so that its people are orderly and the country has much income. In Singapore, people who smoke everywhere are fined $\$ 1,000$ or equivalent to $\mathrm{Rp}$. 10,000 The government provides facilities for people to smoke, but cigarettes must be finished at that place if they will not be fined. If only the Indonesian government could make such strict regulation, then the Indonesian generation would be free from deaths from smoking.

The problem of smoking is not only the responsibility of government but ourselves as a society and government to reduce nicotine waste in our beloved country. The problem of smoking can be overcome by making strict regulations for smokers, holding socialization and increasing public interest in reading by the government and intellectuals, as well as people who dare to reprimand smokers who smoke anywhere in the public interest. Thus, Indonesians' lungs will be free from the contamination of addictive substances and nicotine produced by cigarettes.

\title{
4 CONCLUSION
}

The poetry of Taufik Ismail as literary works succeeded in explaining quite detailed and complete about social facts of smoking in Indonesia. Through these facts, it can be seen that the poetry revealed about cigarettes in Indonesia which have indeed reached such a level of concern. The Poetry can be used for media awareness, reflection, and more in-depth thoughts about cigarettes. Thus, through an understanding of the dangers of smoking, the adverse effects of smoking can be prevented or reduced. More specifically, by poetry, it can be used as a medium for planting the character of the dangers of smoking to stop the smokers' generation and reduce cigarette consumption in Indonesia. So that readers can draw their conclusions about the good or bad considerations of smoking. 


\section{REFERENCES}

[1] S. R. Hamdan, "Pengaruh Peringatan Bahaya Rokok Bergambar Pada Intensi Berhenti Merokok," MIMBAR, J. Sos. dan Pembang., vol. 31, no. 1, p. 241, 2015, doi: 10.29313/mimbar.v31i1.1323.

[2] M. N. Amalia, “Analisis Pengaruh Konsumsi Rokok Terhadap Produktivitas Tenaga Kerja Di Indonesia,” J. Pendidik. dan Ekon., vol. 01, no. 2015, pp. 1-7, 2017.

[3] Faruk H. T., Pengantar sosiologi sastra: dari strukturalisme genetik sampai postmodernisme. Yogyakarta: Pustaka Pelajar, 2014.

[4] R. D. Pradopo, Beberapa gagasan dalam bidang kritik sastra Indonesia modern. Yogyakarta: P.D. Lukman, 1988.

[5] Sugiyono, Metode Penelitian Kuantitatif Kualitatif dan R\&D. Bandung: Alfabeta, 2009.

[6] Faruk H. T., Metode penelitian sastra. Yogyakarta: Pustaka Pelajar, 2012.

[7] Kementrian Perindustrian Republik Indonesia, "Data Perusahaan Industri Rokok di Seluruh Indonesia." [Online]. Available: https://kemenperin.go.id/direktoriperusahaan? what=rokok\&prov=\&hal=3. [Accessed: 08-Jan-2020].

[8] Direktorat Jenderal Perimbangan Keuangan, "Proporsi dan Estimasi Penerimaan Pajak Rokok untuk Masing-Masing Provinsi Tahun Anggaran 2018." [Online]. Available: http://www.djpk.kemenkeu.go.id/?p=5600. [Accessed: 08-Jan-2020].

[9] "Sejarah dan Asal Usul Rokok di Dunia dan Indonesia." [Online]. Available: https://www.tobakonis.com/rokok/sejarah-rokok-dunia-indonesia/. [Accessed: 08-Jan2020].

[10] "Peraturan Pemerintah Nomor: 27 TAHUN 2012 ." [Online]. Available: https://engine.ddtc.co.id/peraturan-pajak/read/peraturan-pemerintah-27-tahun-2012. [Accessed: 07-Jan-2020]. 